\title{
SOCIAL POLICY AND THE INDIAN EXODUS FROM EAST AFRICA
}

The exodus of British Indians from East Africa to the United Kingdom after 1966 had its roots in two phenomena. The better known was the quest for Africanisation in Kenya and Uganda. The other relevant phenomenon was, in fact, the Europe a $\mathrm{n}$ is a t i o $\mathrm{n}$ of Britain - the change of direction in British policy and self-conception from a Commonwealth emphasis to a European emphasis.

Let us first look at the attempt by Kenya and Uganda to promote greater indigenous involvement in local commercial activity, and then look at developments in Britain as a factor behind the Indian problem in Anglo-African relations.

Uganda and Kenya have differed from Tanzania in their approach to the economic transformation of their peoples. On July 4, 1966 Uganda's National Assembly approved the National Trading Corporation Bill setting up a new body to accelerate African participation in trade and commerce. This was the culmination of a number of different experiments and appeals by the Uganda Government to achieve greater indigenous involvement in these sectors of the economy. A month before the passing of the Bill setting up the new body, the Minister of Commerce and Industry told a meeting of the National Economic and Social Advisory Council that a situation had to be created in which Africans could be helped to become commercially effective. "They must learn commercial trícks and trade tricks, and be ready to burn their fingers." It was easy to open a shop, but it needed perseverance to keep it open.

There definitely seems to be a groping by the Uganda Government for methods by which Africans could learn, in the words of the Minister, "commercial tricks and trade tricks and be ready to burn their fingers". And the National Trading Corporation was intended to facilitate this process of experimentation with African involvement in commercial activities.

In 1967 there was a slight unease among non-African businessmen. In Tanzania there had been direct nationalisation by the State of certain industries. In Kenya and Uganda there seemed to be increasing militancy in the process of Africanising commerce. The Uganda Government decided that a reassurance was needed for the non-African businessmen. Addressing the Uganda Chamber of Commerce at its Annual Meeting Mr. C. J. Obwangor, then Minister of Commerce and Industry, urged the businessmen not to regard the National Trading Corporation as a threat to them - "It is not this Government's intention to see that all non-African businessmen go out of business. Far from it, it is the intention to see that there is a proper balance between Africans and non-Africans in the distributive trade." The Minister asked the businessmen to co-operate in achieving greater racial integration in commerce. Private enterprise had a challenge to meet. The Minister asked the businessmen to rally the best qualities of business on the issues of integration as on other issues. "I do look for an attitude of energy, vigour, and of willingness to take reasonable risks", Mr. Obwangor asserted.

As part of this process of economic re-socialisation the Uganda Government has sometimes put faith in commercial education and training. Training in accountancy, book-keeping, secretarialship and even personnel management do not of course constitute an induction into entrepreneurial behavior. But such education is perhaps a supportive factor in the whole growth of economic readjustment and psychological re-orientation. In May 1966 the Minister of Education announced that new steps to expand the range of commercial education in Uganda were being taken. Some of these steps affected the new role of the 
Uganda College of Commerce which was already in existence but whose scope was under review. Discussions between the Government and Makerere University College later led to a scheme to introduce accountancy at degree level at Makerere, supported by legal studies with a special orientation towards business law. A beginning was made as from July 1968 in accountancy at this level with the legal support for it. The Uganda Ministry of Education envisages instituting a commercial diploma course at university level or perhaps a degree in business if there is agreement with the different authorities concerned.

To some extent this is an attempt to utilize the mystique of education as a way of giving an extra boost to the reputation of commercial activity. The craze for education in East Africa is already striking, and initiatives towards its acquisition are the order of the day. But the attraction of commercial activity itself is as yet uncertain. Could the mystique of education be utilized to create a mystique for commerce? And is commercial education the right approach towards this transplantation of prestige?

To some extent the skills which are being asked for in commercial education continue to be purely supportive rather than fundamental to the creation of an African commercial class. Nevertheless the new faith in training for business and private enterprise is part of this Ugandan groping for effective means of economic re-socialisation.

Kenya's policy in this sphere of national life has been strikingly similar to that of Uganda. To some extent Kenya's problem has been more severe. After all, some kind of successful middleman economic activity by Africans had a longer history in Uganda; prosperous African farmers and merchants were known well before independence. In Kenya, however, the growth of an African prosperous class was much more manifestly a post-independence phenomenon. Farming in Kenya had continued to be dominated in its cash crop aspects by Europeans. And distributive trade was overwhelmingly in the control of Europeans and Asians. A re-settlement scheme in the Kenya Highlands helped to give an increasing share to Africans in this sector of the national economy. But there was still a good deal to be done. Progress in the commercial sector was in many ways less spectacular than the re-settlement schemes. Here again then there was an early commitment to the Africanisation of commerce and to the creation of an effective African business class. The Government Sessional Paper No. 10 on African Socialism was in part an undertaking to Africanise the rudimentary capitalism which Kenya had already created.

At first the methods used were mainly those of a p pealing to immigrant businessmen to involve more and more Africans in the activities. But one major difficulty was the fact that many Asian businesses were essentially family businesses which did not lend themselves very easily to acquiring partners outside the family circle. Since the whole distribution of work and method of involvement had a strong personal element rooted in family relationship, it was not easy to find a place for a new African partner in the business.

In addition the very idea of creating an African commercial class was inevitably a matter which could undermine seriously the livelihood of some of the poorer shopkeepers among immigrant communities. Here again it was at times like inviting certain Asians to commit commerical suicide. There was a third reason as to why the initial loose appeals to Asians that they help African businessmen did not yield immediate results. This was the simple fact that Africans were seldom effectively competitive in commerce even when given a little push. This last brings us back to the whole problem of attempting economic re-socialisation as a prerequisite for the creation of an effective African commercial class.

Mr. Francis Nduati Macharia is one African businessman who achieved sufficient eminence to become President of the Kenya National Chamber of Commerce 
and Industry, the country's main organisation of businessmen. In an interview late in 1967 he implied that the African in Kenya had yet to acquire the discrimination and single-mindedness which would enable him to affirm that tautological proposition that "business is business" - and is not something else. In the words of Mr. Macharia, "Many Africans are completely confused. They don't know whether they want to do business or farming or something else - and there is a tendency to look on business as a hobby".

Partly because of these considerations the Kenya Government had in any case by then become increasingly militant in its policy of trying to push Africans into effective business behaviour. One method used was simply to reduce the opportunities open to non-Africans in the hope that the gaps left would draw in those Africans who might otherwise have been too timid or too disorganised to be fully competitive with the previous holders of such opportunities. Out of this grew the whole idea of the Trade Licensing Bill designed to Africanise trade. The method was to licence business in Kenya more systematically and limit the duration of licences to one calendar year. The Minister was to have a right to refuse a non-citizen a licence if he was convinced that a business could be done by a citizen. It is true that measures of this kind were in principle intended to be non-racial; and those immigrant people who had already taken Kenya citizenship were not to be penalized. But ultimately the purpose was indeed to achieve a greater Africanisation of some of these openings.

Indeed the openings themselves could only by created by a deliberate elimination of some Asians and Europeans from these businesses. This side of the Kenya Government policy has been designed not to increase African competitiveness but to decrease the competition that the African has had to face from others. It is hoped by policy-makers that the security which these new African businessmen would enjoy might gradually have healthy demonstration effects on other aspiring Africans. The later generations of African merchants might be forced to manifest a more meaningful faith in risk-taking than this over-protected first generation is being called upon to do.

But the Kenya Government is also utilizing other methods of economic transformations. This one we have mentioned so far is that of trying to reduce or eliminate non-African participants in this sector of the economy. But other measures are intended to increase the number of African traders without necessarily ousting their rivals. One case in point is the undertaking by the Ministry of Commerce to distribute shares widely at cheap rates from at least one major Asian industry in the country. The industry was itself offering the shares to the Ministry for this kind of distribution, and intended to attract significant African participation into what had previously been a large family business. These were the shares of the House of Manji which Minister Mwai Kibaki undertook to try and distribute widely in February 1967. The Kenya Government seemed convinced by the proposition that one could only learn to invest by investing. Africans had therefore to be encouraged to take the risks of buying shares and familiarize themselves with this exercise. At times Kenya policy has echoed the policies which were pursued in Sweden in the 1950's - the ideal of trying to create "an ownership democracy".

Given this kind of emphasis towards the indigenization of commercial activity in East Africa, it was understandable that the local Indians and Pakistanis holding British passports should feel more and more insecure about the future. But what precipitated the exodos to its maximum proportions was the growing movement in Britain in favour of restricting immigration. Duncan Sandys and Enoch Powell soon created sufficient worry in Britain to make stricter immigration control an imminent possibility. At first many Indians in East Africa were reluctant to believe that Britain would stop people holding British passports from going to 
Britain, which was legally their hope. There were many British Indians who naively believed that such an act would be so contrary to international law and usages that the United Nations as well as other powers would exert pressure on Britain to desist.

But it was soon clear that the gates of Britain were going to come down. It is this factor more than any single one which decided the issue for many East African Indians. Panic was created as they visualised their chances of ever entering Britain diminishing rapidly unless they left for Britain there and then. The great majority of those who migrated were under no immediate danger from the Kenya Government - but they could not take the risk of waiting until they were threatened. By that time it might be too late.

It is a contention of this paper that Britain's readiness to divide citizenship on the basis of race, and readiness to alienate India and Pakistan as well as East Africa on such an issue, was directly linked to her disenchantment with the Commonwealth and her fascination with the European Economic Community and what it meant in terms of a new role and a new sense of identity for Britain.

There seems to be little doubt that the racial theme is present in Britain's new Pan-Europeanism. A sense of having been rejected by the Asians and Africans, and being put in the dock for the sins of Britain's imperial history, have alienated significant elements in the British population. The British are beginning to feel like strangers in the big wide world, and are therefore compelled to look more closely at their European neighbours in a quest for familiarity. What is familiar is often comforting and capable of affording a sense of security. The neighbours across the English Channel were indeed once looked upon as total aliens. In many respects they are still so regarded. But it has hit the British people with a renewed emphasis that continental Europeans even at their most alien are perhaps less incomprehensible than, say, the Pakistanis.

There seems to be little doubt that the most dramatic rise in racism within the Commonwealth in the last five years has taken place in Britain itself. In many parts of the Commonwealth racialism has in fact been on the decline within the same period. In Asia especially all indications seem to suggest that anti-white militancy as such has considerably subsided in the last decade or so, though anti-Westernism as an ideological stance might still be important. Opposition to the American omnipresence in the world, for example, might have increased in Asia. Disapproval of Britain as a collaborator in the special relationship with the United Staes might also have significant depth in Asia. But the old animosities against white people as such seem to have gone down.

By contrast anti-coloured feelings in Britain have probably attained an all time high. A substantial reason is of course the immigration of significant numbers of people from India, Pakistan and the West Indies coming to settle in Britain. Job competition between whites and coloured people, cultural differences in racially mixed neighbourhoods, a sense of resentment against too many new comers from coloured lands, have all contributed their share to the rising tide of British racism. There seems to be little doubt that the Commonwealth Immigration Act of 1968 was a piece of racialistic legislation. British citizens of IndoPakistani extraction were from then on to be given discriminatory credentials as regards entry into Britain. The world came to witness a blatant acceptance of the principle of two classes of citizenship by a British Government and a British Parliament. And even the legislation which was being put forward by the Labour Party, far from being a sign that the British Government was more racialistic than British Society, was probably an effort by the British Government to contain that rising tide of popular racism which was manifesting itself in significant sections of the British population. 
Increased racial feeling in Britain might therefore be said to have independent causes from increased Pan-Europeanism in Britain. But the two feelings seemed to have inter-acted and to some extent reinforced each other. From the ranks of British Conservatives for example are to be found both staunch Pan-Europeanists and staunch supporters of British withdrawal from relations with coloured nations of the world. There are, of course, people who are sincere Pan-Europeanists without being even remotely racialist. But one cannot help feeling that there is a considerable section of the British population for whom the two emotional orientations are mutually reinforcing.

We have said that racialism in Asia seems to have declined while racialism in Britain has increased. What of racialism in Africa? It would be idle to overlook some Indophobia in East Africa. What has happened in Africa seems to be neither an increase in racial militancy nor a reduction thereof, but a change of emphasis. On balance there is less anti-British feeling in East Africa today than there was five years ago. But there might indeed be more anti-Indian feeling in East Africa today than there was five years ago. The great objection to the British, and the resultant tensions between whites and Africans, was basically derived from the colonial relationship. Once British colonial rule was withdrawn a major cause of anti-British feeling was semi-neutralised. Arrogant British settlers, or extra-assertive British District Commissioners, were no longer loose on the East African countryside. But Indian shopkeepers are still around, and they pose not only competition for African traders but also on occasion a relationship of condescension with the African customers and neighbours. The exclusiveness of the East African Indians is often exaggerated, but they are exclusive in their social relationships and not always tactful in their general attitudes. The policies of the different African governments to Africanise commercial activity have also heightened tension between Africans and Asians in East and Central Africa. If there is significant racialism still remaining in East Africa, it is less anti-white and more anti-brown than it might once have been. And the Indophobia is, on the whole, by no means the central factor in the Africanisation of commerce in Kenya and Uganda. The real ambition is to foster African economic participation in national life.

Ali A. Mazrui 